\title{
ДЕЛА ФЈОДОРА МИХАЈЛОВИЧА ДОСТОЈЕВСКОГ НА БЕОГРАДСКИМ ПОЗОРИШНИМ СЦЕНАМА
}

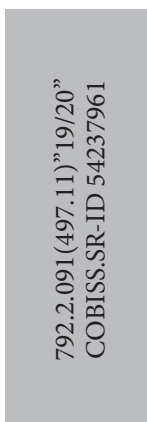

\begin{abstract}
Апстракт
Циљ студије је да прикаже инсиенаиије по делима Ф. М. Достојевског на театарским сиенама Београда (Народно позориште, Југословенско драмско позориште, Београдско драмско позориште, Атете 212, Позориште Мадленијанум, Позориште Славија) током двадесетог и прве две деценије двадесет и првог века. Истраживане смо спровели архивско-историјском методом на материјалу приказа и рецензија позоришних представа, које су објављивали у дневној итампи (Политика, Правда, Време, Експрес), периодичним изданима (Кғьневне новине, Нин) и засебним студијама и монограбијама, истакнути позоришни критичари и теоретичари Душан Крунић, Велибор Глигорић, Ели Финци, Петар Волк, Јован Христић, Слободан Селенић и други. Поред овога у раду су коришћени и ТВ и радио записи, библиографске публикације и други архивски материјали.

\section{Къьучне речи}

Фјодор Михајлович Достојевски, Београд, позориште, драматизација, представа
\end{abstract}

Интерес за дела Фјодора Михајловича Достојевског (Федор Михайлович Достоевский), на позоришним сценама Србије, започиње веома рано, већ почетком XX века, и траје до данас. Студија је конципирана на најважнијим моментима бројних инсценација Достојевског у Београду, премда на територији целе Србије његова дела већ два века представљају основу репертоарске политике већине позоришних кућа. Достојевски је на српску сцену закорачио 8. децембра 1907. када је први пут на сцени Народног позоришта изведена драматизација Злочин и казна (драмска

1 dcbiljan@gmail.com 
сцена у десет слика, с епилогом). Драматизацију је урадио J. А. Делије, превео А. Лучић, а режирао Милорад Гавриловић, глумац и редитељ. Ово су уједно и једини оскудни подаци о представи. Такође, има мало података о премијери Браћа Карамазови, по драматизацији Жак Копоа (Jacques Copeau) и Жан Круеа (Jean Croué), у преводу Живка Фртунића, а режији Александра Ивановича Андрејева (Александр Иванович Андреев) изведеној на сцени Народног позоришта, 30. октобра 1913. Многе поставке, у различитим драматизацијама, доживели су и комади настали по романима Зли дуси, Браћа Карамазови, Идиот, Ујкин сан. После неколико гостовања Художественог театра које изводи Достојевског на сценама српских позоришта $(1914,1920,1921$, и 1924) и трупе MXAT-а са представом Село Степанчиково (1925), готово да нема позоришта, које бар једном у сезони, није у репертоар уврстило премијеру, по неком делу великана светске књижевности. На нашим позорницама највише су извођене драматизације Злочина и казне, Идиота, и Браће Карамазов, док су комедије (Ујкин сан, Туђа жена и муж под креветом) и кратке приче (Кротка, Домаћица, Настасја Филиповна, Село Степанчиково) извођене повремено и представљале су изазов редитељима и публици.

\section{Ујкин сан}

Ујкин сан на сцени Народног позоришта у драматизацији Карла Густава Волмелера (Carl Gustav Wolmelier) по Достојевском, у преводу Милана Беговића, сценографији и костимима Владимира Жедринског, режирао је Јуриј Љвович Ракитин (Юрий Львович Ракитин). Комад је премијерно изведен 14. маја 1930. У подели су били великани српског глумишта, а рецензенти су хвалили поставку о чему сведоче критике у Времену, Правди, Политиนи и другим писаним гласилима оног времена.

Драматизација новеле Ујкин сан Слободана Стојановића, у режији Боде Марковића, сценографији Миомира Денића и костимима Љиљане Орлић, изведена је у Народном позоришту, 26. јуна 1982. Играли су: Ксенија Јовановић (Москаљова). Душан Јакшић (Москаљов), Огњенка Огњановић (Зинаида Афанасијевна), Предраг Тасовац (Кнез) и други.

Представа је изазвала контраверзне коментаре, од салонског каламбуpa, на радост публике, до сна и дипломатије, као и инсинуација на бајку о цару Лењину. Као илустрација, може да послужи критика Дејана Пенчића Пољанског 
Добар повод да се направи допадљива, забавна представа, али се овог посла прихватио Бода Марковић, редитель који је имао веће амбииије. Што је и разумљиво, када су ретко у прилиии да раде у великим позориштима, као што је случај са Марковићем, онда се редитељь труде да се покажу, да свима ставе до знань, како су неоправдано у другом плану [...] Зато од ове веселе игре покушава да гради гротеску на тему људске похлепе. [...] Ксенија Јовановић (Москальева), следи дисииплиновано редительа, али резултат ни юој ни Марковићу не служи на част [...] Сви се глумии муче и упиғу, успевајући углавном само да протерају смех са позорнице. [...] Наговештаја оног што се хтело има у игри Горјане Јағић (Зјаблова) и Добриле Ћирковић (Карапухина) [...] Код Славке Јеринић има више наговештаја. [...] Ћирковићева је ускочила у улогу, пошто се Славка Јеринић, разболела. [...] Кнеза је радитељ доделио Предрагу Тасовиу [...] Једино успело решене виђено је у финалу представе. Док глумии траже несталог умрлог Кнеза, дотле овај сенилко којим су хтели да се поиграју, а он их је све изиграо, туби руке лепотицама у гледалишту. Успело решење, само касно пласирано. (Пољански 1982)

\section{Туђа жена и муж под креветом}

Туђа жена и муж под креветом премијерно су одиграни на Сцени у Земуну, Народног позоришта у Београду, 15. децембра 1976. У преводу и адаптацији Мирка Милорадовића, водвиљско весело позорје Достојевског режира Цисана Мурусидзе. Сценографију потписује Миодраг Табачки, костиме Божана Јовановић, избор музике Звонимир Јовичић а кореографију Борис Радак. Играју: Мија Алексић (Иван Андрејевич Шабрин), Бранка Зорић (Глафира), Драган Зарић (Младић) и други. Критичар Слободан Селенић окарактерисао је новелу као „хир великог писца" (Селенић 1976), док за дело раног Достојевског, Дејан Пенчић Пољански говори:

Радна је логично вођена, изненађена, неочекиваних обрта је мало да би се задоволили драматурики захтеви водвиља. [...] Повод за позоришну играрију, Цисана Мурусидзе и глумии, у првом реду Мија

2 Једна од најуспелијих позоришних адаптација Достојевског, на нашим просторима (која нажалост излази из оквира наше теме) јесте режија новеле Ујкин сан Егона Савина, која је премијерно изведена на сцени Српског народног позоришта у Новом Саду 6. октобра 2006. 
Алексић, одлично су искористили и позоришна публика је добила шармантну и забавну представу. Миодраг Табачки аутор је сценографије у којој доминира кревет ииновских димензија. Са сценограбијом се одлично допуғују костими које је креирала Божана Јовановић. Музика (Звонимир Јовичић) и кореограбија (Борис Радак) испуниле су важну функиију стварағь атмосфере [...] .љубоморног мужа Ивана Андрејевича Шабрина игра Мија Алексић. Мија је још једном показао како се од улоге која не пружа много могућности, кад глумаи има маште и духа, може да се уради много. [...] Добрила Ћирковић, Зорииа Мирковић, Союа Јауковић, Предраг Тасоваи, Драган Зарић, Бранка Зорић и Бранимир Замоло, добро су одиграли своје улоге и успешно испунили редитетев захтев. Мија Алексић је показао шта се глумиу не може задати. (Пољански 1976)

\section{Кротка}

Кротка, „фантастична приповетка” Достојевског, играна је заједно са Госпођицом Јулијом А. Стриндберга, на сцени Југословенског драмског позоришта 3. марта 1961. У преводу Десанке Максимовић, режију и адаптацију урадио је Јован Путник. Сценографију је потписао Миленко Шербан, костиме Мира Глишић, а маску Карло Булић. Играју: Славко Симић (Лихвар), Радмила Ђуричин и Снежана Никшић (Кротка), Капиталина Ерић (Лукерија). Ели Финци сагледава представу као интелектуалну страст редитеља Путника, за трагањем у непознато и скривено.

Улогу Лихвара, који је једино тице ове приповетке, тумачио је Славко Симић. Ако је Симић прибегао благом рационализовағу тика, треба рећи да би без таквог упрошћавана и осиромамавань, уопште био немогућ било какав сиенски приказ. Лик Кротке, која се јавља као Лихварова успомена, сачињена од носталгије и гриже савести, дала је Радмила Ђуричин дискретно и тупко, док је Лукерију тумачила Капиталина Ерић, конзистентно и постојано. (Финци 1961)

\section{Село Степанчиково}

Село Степанчиково у преводу Милана Кашанина, драматизацији и режији Арсенија Јовановића, изведено је 15. марта 1974. Сценограф је Петар Пашић, костиме је радио Љерка Калачић, а музику Ивана Стафано- 
вић. Играли су између осталих Мија Алексић (Фома Фомич), Предраг Тасовац (Ростањев), Бранислав Јеринић (Бахчејев) и други.

Народно позориште имало је много невоља при реализацији пројекта, тако да су стручњаци позоришта изражавали сумњу у дуговеки живот представе. Много времена и новца потрошено је да би продукција ове представе, најзад, доживела позитиван епилог. Критичари су били подељени у рецензијама, поједини су изрицали негативне судове, док су други хвалили представу. Но, једно је сигурно у чему се сви слажу, а то је игра Мије Алексића као Фоме Фомича, који је бриљирао те вечери. Рецензија Дејана Пенчића Пољанског изразито негативна уочава да је за све крива драматизација, конфузна и лоша:

Арса Јовановић изгледа да је сматрао довотним да из романа пренесе само делове писане у драмској форми (дијалоге Достојевског), заборавтајући да се низ значајних података о личностима и причи налази једино у размиштьғьим студента Сергеја Александровича (Предраг Ејдус) који приповеда историју Степанчикова и юегових житель. Гледалаи који није читао дело, био је у проблему. [...] Недостатке сопствене драматизаиије, редитељь није могао да ублажи. [...] Сценографија Петра Пашића била је, чудна и недоследна [...] Драматизација је онемогућила глумие да остваре добре улоге. [...] Изузетак је Мија Алексић у улози Фоме Фомича. Од прве појаве на сиени Фома Фомич Мије Алексића, био је једина кохезиона сила и највиши уметнички домет представе. Предраг Тасоваи као Јегор Илич Ростанев имао је најтежи задатак [...] да учини тик животним [...] Повремено успевајући у томе, Тасоваи, заслужује комплименте. Остали, у распону од коректних Бранислава Јеринића и Богића Бочковића, до потпуно неприхваттивих Наде Шкриюар, Бранке Зорић и Микија Манојловића. (Пољански 1974)

Критика Петра Волка тврди пак супротно:

Дело је једно од слабијих у опусу великог писиа. [...] Асоиијације на Молијеровог Тартифа су очигледне [...] Над сиенографоским простором, који обухвата велику сиену надвила се тамна ноћ са безбројним звездама. [...] Костими Љерке Калачић су допуюавали амбијент [...] Врлина драматизације је у томе што се држала Достојевског [...] поведен текстом редитељ настоји да изведе причу о свакој тичности, сваки глумаи добија могућност израза. [...] отуђеюе незадржи- 
во проваљује у људе. [...] Фома Фомич постаје управо израз таквог стағьа, губи интегритет...nодређује се опсенама, глупостима [...] У односима између Фоме Фомича (Мија Алексић) и Јегора Илича Ростанова (Предраг Тасоваи) и Сергеја Александровича (Предраг Ејдус), студента и нећака. [...] Мија Алексић има замаха, сигурности, снаге експресивности толико да у сваком часу пред собом имамо великог глумиа. У контрасту с тим је Јегор Илич коме Предраг Тасоваи, даје доброту, лакоћу. [...] Ако је Алексић једна теза, онда је Тасовач, друга, па се међусобно објаштьавају [...] ово је заиста вредан резултат [...] Сергеј Александрович је врло дискретне интерпретаиије Предрага Ејдуса са суптилним нијансама и изразом који плени својом искреношћу [...] Село Степанчиково није рутинска представа. У ту је Арса Јовановић уложио много знана, подигао је заједно са глумиима на ниво који се захтева у Народном позоришту. (Волк 1974)

\section{Записи из подземља}

Записи из подземља играни су као монодрама, а одржали су се на репертоару Народног позоришта више деценија, почев од премијере 13. марта 1973, захваљујући младом редитељу Славенку Салетовићу и извођењу Миде Стевановића. Представа је играна на малој сцени Театра круг 101, а критичари су позитивно оценили поставку, као живу реч Достојевског, која у интерпретацији Стевановића добија на значају, јер монодрамом доказује величину и таленат.

На сцени „Бојан Ступица”, Југословенског драмског позоришта, премијерно су приказани Записи из подземта у драматизацији и режији Ане Ђорђевић 11. маја 2010. Сценографију је радила Весна Штрбац, костиме Лана Цвијановић, а звук дизајнирао Вледимир Живковић. Улогу Човека играо је Срђан Тимаров, а остале су тумачили Марко Баћовић, Јелена Тркуља, Маринко Маџгаљ, Бојан Лазаров, Ђорђе Марковић и Слободан Тешић. Редитељка Ана Ђорђевић сачинила је личну и особену драматизацију, не везујући се за Русију деветнаестога века, али задржава теме, мотиве и значења дела о једном малом, сивом чиновнику који за себе каже да је болестан и зао човек. Кроз његове неуспеле контакте са другим људима, који јуре за новцем и функцијама, као и покушај везе са младом проститутком, преиспитују се етички принципи. Главни јунак, жељан је љубави и смисла, али и сам је суров према дугима, не налази 
веру чак ни у могућности промене. Представа у духу антрополошког песимизма, дешава се у неодређеном времену и простору, а по свом значењу тиче се животне ситуације савременог појединца.

\section{Злочин и казна}

Представа Злочин и казна у Народном позоришту изведена је 26. марта 1935, по драматизацији Краснопољског (Павел Филимонович Краснопольский) у преводу Велимира Живојиновића, а режији Николаја Осиповича Масалитинова (Николай Осипович Масалитинов) и сценографији Владимира Жедринског (Владимир Жедринский). Улогу студента-убице, одиграо је Раша Плаовић. У то време, млади критичар, на почетку каријере, левичар и члан Комунистичке партије у илегали, Велибор Глигорић, некритички и пристрасно пише о представи, негативно оцењујући драматизацију и режију, а хвалећи главне тумаче рола. Између осталог тврди:

Узиманем драматизације Краснопольког није се водило рачуна о преображеном духовном интересу данашнице [...] драматизација није успела да извуче оне још живе изворе психолошких дубина Достојевског, док с друге стране није га ослободила од мистичне материје која не пријаюа за интересе данашне публике. Драматизација је ослабила и она места која кулминирају трагичним емочијама, а извесним застарелим позоришним решенима умртвила је веома живе психолошке акције [...] Драматизација није успела да реши увод Раскольикова у злочин [...] Масалитинов, један од првака Московског художественог театра, решавао је овај комад у традицијама позоришта из кога је изашао. Овакво решаване по типу Художественог театра, изискује дубоке и утанчане глумачке студије [...] Маслатинов редительки рад није до краја спровео [...]. Као редитель није суверено владао ансамблом, а без те суверености юегов рад ужару Художественог театра није могао дати богатије резултате. Г. Раша Плаовић је унео у тумачене Раскољникова сву своју нервност која је са те стране створила улогу драмски врло импресивну. Нарочито је та нервност снажно дејствовала у изразима душевне грознице Раскољникова. С друге стране, игра Плаовића није била доволно психолошки дубока и интензивна [...] Сусрет Расколникова са Союом у кабани није изражавао юегову оданост Союи од првог виђена. Затим негова исповест Союи, као и юегова посета мајии, нису носили 
у себи величину трагичних емочија. Игра г. Живановића била је, а то је заслуга режије Масалитинова, изненађене. Г. Живановић је дао веома интересантан тип судије Порфирија. Психолошки компликовану улогу Живановић је доста успело савладао давщи јој врло живе карактеристичне израде и лепе психолошке нијансе. Имали смо пре ове роле, маестрално тумачене Порфирија од стране Павлова [...] Јом један пример да у нашој трупи има интересантног глумачког материјала из кога добре редительке руке могу извлачити јаке глумачке креачије. Г-ђа Милошевић дала је добар лик Союе у юеном бледилу... нена Союа вище тичи на једну скромну и побожну калуђерицу, него на несрећну проститутку. Г. Душановић као Разумихин је био окретан и жив. [...] Г-ђа Арсенић је приказала мајку местимище без трагичне ноте. [...] Г-ияа Косова дала је Дуюу без дирливе топлине и узбуђености. [...] Г. Новаковић као Мармеладов био је изразит у типу. [...] Г-ђа Паранос није ушла у живописни и доброћудни тип припросте Настасје. Г. Билуи, Заметов морао би се ослободити рогобатног изговора. (Глигорић 1935)

20

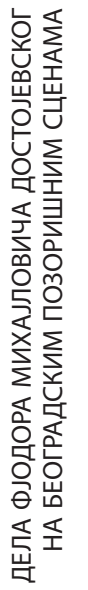

Једна од првих поставки Злочина и казне, после Другог светског рата, била је 21. новембра 1953, на сцени Београдског драмског позоришта. Превод, драматизацију и режију потписује Миња Дедић, сценографију Душан Ристић, костим Данка Павловић, а музику Војислав Симић. Глумачку екипу чине: Љубивоје Тадић (Раскољников), Сима Јанићијевић (Порфирије Петрович), Раде Марковић (Разумихин) и други. Сећајући се једне од првих значајних улога, Љуба Тадић о Раскољникову говори:

Миюа Дедић је знао доста о позоришту и сјајан је редитељ. Не знам како сам играо Раскольникова. Међутим, ја ништа нисам морао да додајем Раскољникову, тако сам живео. Тих педесетих година Београд је био језив. Владала је ужасна глад. Када је дочао Раскольнков, почео сам да верујем да човечанство може да се спасе ако једну бабу убијем! Ииао сам у иинелу, иемперу и чизмама из Црвеног Крста из Симине улице. У првом делу сам се просто исповедао, тако сам то играо. (Тадић 2002)

Критичар Ели Финци констатује:

Раскољникова је тумачио Љубивоје Тадић. Сав юегов израз да кршитель тьдских и божјих закона, који се слама под теретом закона, прикаже у противречности смеле богоборачке мисли и ситних 
тьудских емоција, као сложену тичност којом управтају дубинске струје идеја и расположена, више је остао у хтену него у оствареном резултату. Често где је намеравао да искаже сложену узбуђеност духа прелазио је у психопатолошку раздраженост, где је хтео да израз обоји дубином преломио га је спольном патетиком. Само у неколико сиена код иследника успео је да да пуну меру једноставности која подразумева сложеност. (Финци 1953)

За разлику од Финција, Слободан Селенић уочава:

Висока, исирпљена, у дугачку жуту косу обрасла, ванредно пронађена маска отупелости од бола унутраштих раздирағь, говор немелодичан, искидан, са неприродном интоначијом - Љуба Тадић, као Раскольников је једна од тичности коју ће позоришна публика на Црвеном Крсту најдуже носити у сећағу. Истина, Тадић још није завршена глумачка физиономија. На моменте фрапантно уверлив, потресен, тако да заједно са Достојевским нагони публику, да се осећа као код зубара. Тадић претераним гестом, сувише гласном интонацијом или само за секунду неприкладном маском сам руши илузију коју је веома вешто, брижтиво и упорно до тог тренутка градио. (Селенић 1953)

Критичар Слободан А. Јовановић тежиште приказа поставља на драматизацију Злочина и казне:

Посао је тај и претежак и прелеп...И Миюа Дедић, млади београдски редитель, с ним се понео [...] У првом плану Миюа Дедић - како је изјавио у дневној штампи - имао је пред очима две већ постојеће драматизације: руску и франиуску. Оне по тьеговом мищленьу, нису битност Достојевсковог романа правилно преносиле на гледаои, јер су упућивале и подвлачиле религиозан тренутак, који је у роману спореднији ако не и споредан. Битност дела је у друштвеном тренутку, у економској општој условљености. Расколников је само индивидуални одраз те условльености, одраз кроз индивидуални стваралачки експеримент Достојевског. Достојевски у роману то изричито каже. [...] И у оквирима које је себи одредио и наметнуо Дедић је морао срести много тешкоћа стваралачког и сценског карактера. [...] Знајући колико су промене у овом случају неизводљиве, Дедић је дао један угтавном непомичан сценски оквир који је разбио на низ појединости...Све ито је тај оквир могао да прими он је 
укључио у юега, али све что није могао да прими он је одбачио. Између осталог, отпала је и Союина (Тамара Милетић) соба. Сиене с юом Дедић је пребаиио на улииу, у пролаз. Сиена убиства са степеништима која је важна у роману морала је бити прерађена. [...] Због тога су отпале шетне - врло важне за дочараване душевног стана Расколникова. [...] Од сваког појединиа је зависио укупни утисак. У том погледу није можда постигнут неки изванредни успех, али је направтен леп и поштен напор који је иелој представи дао лик озбилног, солидног рада. Свакако да је на врху пирамиде... био Љубивоје Тадић (Расколников).Он је био предодређен да игра ту улогу. И он ју је играо врло студиозно у одређеној унапред утврђеној линији. [...] Таквом игром се постиже импресија али се изневерава основни дух текста, који је психичка двојност Расколникова, који жели да побегне од свог злочина али за којим злочин стално иде и сатерује га. [...] Другу велику улогу имао је Сима Јанићијевић (Порфирије Петрович). Та је улога врло суптилна. Она захтева велику изражајну скалу. Јанићијевић се с том улогом јуначки понео, и многе нене тренутке врло лепо извукао...Приказ Злочина и казне у Београдском драмском позоришту, и као драматурики и као глумачки подухват, представља частан напор и лепо остварене. Он заслужује пуну подршку. (Јовановић 1993: 36-38)

На сцени Југословенског драмског позоришта Злочин и казна изведени су у драматизацији и режији Мирослава Беловића, према преводу Милосава Бабовића, сценографији Петра Пашића и костимима Славице Лалицки. Музику је компоновао Енрико Јосиф. Премијера је била 17. марта 1992. У главним улогама били су: Миша Јанкетић (Раскољников), Бранка Веселиновић (Аљона Ивановна), Неда Спасојевић (Соња), љуба Тадић (Порфирије Петрович), Зоран Ристановић (Свидригајлов) и други.

По реакцијама критике, представа је вратила веру у позориште. Вредело је видети и чути ансамбл Југословенског драмског позоришта. Поводом ове представе Петар Волк је писао:

Када у пригушеном светлу последюег призора Неда Спасојевић (Союа), сугерише Миши Јанкетићу (Расколников) да се поклони свету, клекне и призна злочин, овај романтичарски изазов у гледалишту изазива одушевтене. [...] Беловић је желео да представа буде доживлена као сиенска метабора која своју суштину потврђује у нама. [...] Порфирије Петрович Љубе Тадића добио је не само јасног 
већ и супериорног тумача. [...] Зоран Ристановић (Свидригајлов) је био одмерен, док је Никола Симић (Замјатов) био ненаметлив, Капиталина Ерић као мајка Расколникова, била је убедлива. Виктор Старчић са својим Мармеладовим показао је глумачко мајсторство. Дуюа, Раде Ђуричин била је чедна и дискретних средстава. [...] представа ће вероватно бити радо гледана. (Волк 1971)

На сцени Битеф театра представа Злочин и казна у драматизацији Анджеја Вајде и режији Егона Савина премијерно је изведена 28. јануара 1992. Сценограф је био Тодор Лалицки, костимограф Бојана Никитовић, док је аутор музике била Ксенија Зечевић. Главне улоге су додељене: Предрагу Манојловићу (Раскољников), Предрагу Ејдусу (Порфирије), Тамари Вучковић (Соња), Славку Штимцу (Разумихин) и другим.

Јавност је поздравила поставку Егона Савина, тврдећи да се Достојевски на велика врата вратио на београдску сцену. Критичар Владимир Стаменковић са одушевљењем је тврдио да:

[...] наиме, представа у Савиновој режији а према Вајдиној драматизацији, веома је успела, пружа публици један од ретких, изузетних позоришних доживљаја који узнемиравају из дубине, просто подижу на ноге. [...] Док игра Расколникова, Предрага Манојловића, не поставта пред себе задатак да покаже како се у юеговим грудима сударају тьубав, мржна, гордост и понизност, свирепост и милосрђе [...] пред нама је негов несрећан исход: човек обезглавлен и уплашен, измучен до смрти, дефинитивно поражен. [...] Ово је најбоља Манојловићева улога. Ни Порфирије Петрович којег изванредно игра Предраг Ејдус, није ниита маюе жив, упечатљив лик. [...] И зато тичи на колебльвог пајаиа, који карневализује радюу, чинећи је, по принципу контраста још вище дијаболичном. Уз помоћ двојице глумача треба додати младу Тамару Вучковић (Союа), али и удео сценографа Тодора Лалицког и композитора, Ксеније Зечевић. Савин је сачинио једну од најуспелијих представа по делима Достојевског, коју је ова генерација гледалаца видела. (Стаменковић 1992)

На сцени Југословенског драмског позоришта, редитељка млађе генерације, Ана Томовић, поставља Злочин и казну, такође у драматизацији Анджеја Вајде, према преводу Петра Вујичића, сценографија је поверена Љерки Хрибар, а костими Момирки Баиловић. Премијера је изведе- 
на 8. јуна 2013. Главне улоге су играли: Никола Ракочевић (Раскољников), Љубомир Бандовић (Порфирије Петрович), Милена Живановић (Соња Мармеладова), Богдан Диклић и други.

Идејни концепт Ане Томовић подразумева да је у злочину већ садржана казна, да је то двоје неодвојиво. Раскољников би радо одвојио то двоје, учинио би злочин без казне, јер мисли да он не треба да буде кажњен. Можда неко други треба да буде кажњен, можда неки обичан човек, али он сигурно не, пошто је он даровит човек, способан да на овом свету изговари - нову реч. Казна је саставни део метафизичког питања, питања истине, према којој свака наша акција у реалности има одређену последицу. Може се рећи, акција и последица, уместо злочина и казне.

\section{Зли дуси}

Зли дуси у Народном позоришту игране су у две поставке, настале са специфичном политичком поруком. Реч је о правцу кретања новог времена, о сукобу „западњака” и „народњака”, о политичком и моралном нихилизму.

Прву представу, у два чина, режирао је Арсеније Јовановић, према драматизацији Албера Камија, у преводу Миленка Мисаиловића, док је сценографију и костим радио Душан Ристић. Премијерно је изведена 3. новембра 1968. Главне улоге су играли Љуба Тадић (Ставрогин), Петар Банићевић (Шатов) Милош Жутић (Кирилов), Мија Алексић (Лебјадкин), Вера Чукић (Лиза Дроздова), и други.

Критика је у оценама представе (изведене поводом стогодишњице Народног позоришта) била подељена. Једни су редитељу замерали да је занемарио филозофске димензије текста, да се нашао у вакууму, где је све препуштено фабули и нарацији, док су други сматрали да је Јовановић ушао у све финесе комплексног штива, да је разумео да представа мора имати убрзани темпо и згуснут ритам, те да је реч о правом уметничком делу. Сви су се, пак, сложили да је глумачка екипа одлична и да се посебно издваја Љуба Тадић (у улози Ставрогина, за коју је добио Октобарску награду, 1969). Милосав Мирковић пише: „Сви ми у себи носимо галерију злочесте деце, али је Ставрогин Љуба Тадић, чудовишно дерле на ивици вере и безверја. Његова исповест архијереју Тихону (Миливоје Живановић) била је најбољи део приче и надубљи понор 
драме.” (Мирковић 1968). Такође и Мухарем Первић издваја: „Слабост и крхкост ставрогиновске моћи, поетску светлост ове мрачне душе, њен зао дух, Љуба Тадић је тумачио са дубоким осећањем парадокса људске егзистенције. Ставрогин свакако спада у досад најзначајније креације Љубе Тадића..." (Первић 1968). Критичар Петар Волк о представи је писао као о потпуном успеху и спонтаном усхићењу, јер овакви тренуци у нашој средини нису чести, и та илузија може бити случајност, жеља или плод свесног, уметничког хтења.

Редитель Арсеније Јовановић се стога ни једног часа није измицао у позицију критичког посматрача па ни полемичара у односу на Достојевског. Слично је и са филозофским интенцијама драматизаиије А. Камија - пажна се кониентрише на само збиване као могућност да се управо у юеговој баталној динамици и трагици нађе објаштене за сва тица. Апсурд је виђен уживотном амбијенту [...]. Исповести, очајнички или ситуачије и чиюенице се представтају као појаве у којима се меша реално и иреално, асоцијачије и метафоре, док свака реч не постигне стравичне димензије па је закључак недвосмислен: Достојевски је писаи у којем се одражава не само једно прошло време, већ и ово садашне и много ита од оног ито тек треба да дође. [...] Васа Пантелић (Григорјев) је не само приповедач и посматрач него и учесник. [...] Ма колико Љубиша Јовановић (Степан Верховски) прикривао трагику својим шармом-она избија из сваког нееговог поступка. У том опирану меша се комично са драмским. [...] Његова смрт је истовремено и смрт Варваре тако да Вука Дунђеровић више нема разлога да скрива своја права осећаюа, обистинила се слутьь, све је сломльно и сад видимо да је иео живот био раван опирағуу несрећи и чежни за недостижном срећом. У амбијенту коме припадају Љитана Јанковић (Даша), Марица Поповић (веома упечатльива Прасковја Дроздов), Вера Чукић (којој добро пристаје лик Лизе), Предраг Тасоваи (Маврикије, оиртан готово без речи) [...] Душан Голумбовски (Петар Верховенски) скупио је у себи довольно одлучности да би истрајао са идејама које негирају човека и све тьудско. Њега осветтьввају својим поступиима Милан Пузић (Липутин), Миодраг Лазаревић (Шигалев), Михајло Викторовић (Виргински) и Мирко Милисавльевић (Гаганов). [...] Овакав свет тичи на пакао. Петар Банићевић у снажно наглашеном лику Шатова и Милош Жутић као Кирилов то најпре спознају...поступци су различити чак и схватаньа (ванредна сцена Кириловог самоубиства и Шатове нежности када му се вратила Марија - Милка Лукић). [...] Сви они повезаним 
амбијентом светлости и сенке, мемле. [...] Душан Ристић је ту атмосферу изванредно дочарао. [...] Редитељу је то помогло да појаву Ставрогина учини још чуднијом. Љуба Тадић је домао на позорнииу готово нечујно а таква ће бити и негова смрт... Тадић ту сложену и тешку ролу обликује, као да се припрема за смрт за коју не зна када ће доћи. [...] Тадић управо као призма кроз коју се преламају светови, објашюава и тикове какви су Марија Тимобејевна (у изразу Наде Шкриғьар), нен брат Лебјадкин (у задивтуујућј интерпретацији Мије Алексића). То је свет за себе, на ивици гротеске. [...] У близини су још Фећка, Бранислав Јеринић, Богостав Зорана Ристановића и посебно Тихон у интерпретацији Миливоја Живановића. Овом великом уметнику довољна је и једна сиена па да нас подсети на своје још увек живе могућности. [...] Арса Јовановић је, према томе, своју визију Злих духа изградио на игри љубе Тадића, Миливоја Живановића, Наде Шкриюар, Вуке Дунђеровић, Петра Банићевића, Милоча Жутића, Љубише Јовановића и Мије Алексића. [...] Зато Зли дуси, реализовани у јубиларном расположену (сто година оснивања Народног позоришта, у Београду, 1868-1968, прим. ДЧБ) са гостима у ансамблу, нисуни по чему пригодна представа, већ право уметничко дело и плод свесног стваралачког хтеньа. (Волк 1968)

Зли дуси у драматизацији и режији Стеве Жигона изведени су у Југословенском драмском позоришту, 6. марта 1984. Сценограф је био Борис Чакширан, костимограф Божана Јовановић, а избор музике урадио је Вељко Марић. Главне улоге су играли: Гојко Шантић (Ставрогин), Стојан Дечермић (Степан Верховенски), Чедомир Петровић (Кирилов), Танасије Узуновић (Петар Верховенски), Иван Бекјарев (Лебјаткин), Варја Ђукић (Лиза) и други.

Стево Жигон, важио је за доброг познаваоца дела Достојевског, али поставка Злих духа, по мишљењима критичара, била је промашај. Авдо Мујчиновић вели:

Жигон као драматизатор у овом случају показао се као пуки почетник, он је драматизовао поједине одломке из книге и повезао их у намери да обухвати што ширу прозну материју овог мамутског романа. [...] У реализацији представе Стево Жигон се показао као и у драматизацији, брзоплет и некреативан. Сиенографија Герослава Зарића, од покретних зидова. [...] пре је наликовала на какав шпански него руски комад. (Мујчиновић 1984). 
Овако сложен текст тешко је оживети одговарајућом драмском радњом, али то је, по мишљењу Владимира Арсића, једна од „најзначајнијих вештина коју редитељ треба да поседује" (Арсић 2001: 41-42). Јован Христић, указује да представа „врви од отужних клишеа и оно што смо на сцени видели биле су само празне љуштуре неуротичних стања око којих се ширио дах интелектуалне и емотивне вулгарности." (Христић 1992: 13). Петар Волк у критици открива да је опседнутост Достојевским открила немоћ ансамбла Југословенског драмског позоришта:

[...] месецима су били заокупьени романом Зли дуси онако како га је за сиену приредио славни Албер Ками, а режирао Дејан Мијач, да би пред саму премијеру све одбацили!...Све уништили и почели од почетка са Стевом Жигоном. [...] На крају је остала једна дуга, заморна, досадна представа у којој се појавило свега седам чланова ансамбла и седамнаест гостујућих глумаца!. [...] Неколико глумаца је сачувало достојанство у игри: Гојко Шантић је Николаја Ставрогина, нашао у себи пригушујући страсти са ироничном одмереношћу. Његову мајку Варвару, са пуно ауторитета, тумачила је Босиљка Бочи. Стојан Дечермић је као Степан Верховенски упечатливо оиртао све одлике карактера. Кирилов у игри Чеде Петровића је импресиван, док је Шатов у тумачену Тихомира Арсића носио трагику младости. [...] Иван Бекјарев је Лебјаткину дао праву карактеризачију, а Мирјана Вукојчић је Марију дала надахнуто. Танасије Узуновић у лику Петра Верховенског био је супериоран. [...] Приметни су били и млади Боривоје Кандић и Јасмина Ранковuћ. [...] Зли дуси су велики и залудан труд, јер глумци не могу увек да чине чуда. (Волк 1984)

Зли дуси, у драматизацији (према преводу романа Косаре Цветковић) Тање Мандић Ригонат, која потписује и режију у Народном позоришту, премијерно су изведени 22. новембра 2011. године (сцена „Раша Плаовић”). Сценографију је радио Александар Денић, костим Бојана Никитовић, кореографију Анђелија Тодоровић, композицију Ања Ђорђевић. Улоге су тумачили: Игор Ђорђевић (Ставрогин), Горан Јевтић (Петар Верховенски), Борис Комненић (Степан Т Верховенски), Данијела Штајнфелд (Лизавета Николајевна), Вјера Мујовић (Марија Лебјаткина-Хромка) и други.

Редитељка инсценацију заснива на проналажењу веза са актуелностима српског друштва; у фрагментарну форму текста (30 слика) 
укључује и делове из анархистичких манифеста, што је мана која се одражава у представи - радња се своди на симболичку вивисекцију друштва у коме гомила споредних ликова и токова радње гуше саму радњу. Критичари су хвалили веома добре глумце. У једном интервјуу за Политику (2011) Борис Комненић је поводом премијере изјавио: „Морам да приметим да је код великих наслова највећи проблем, што немам право на грешку. Достојевски је увек савремен. Не може нешто што је квалитет да не буде актуелно. То је нешто што не оставља простор никаквој сумњи. Овај тренутак је идеалан за представу Зли дуси." (Комненић 2011)

\section{Иวันот}

У Народном позуоришту игране су три драматизације Идиота и сцене под називом Настасја Филиповна.

„Десет слика по Достојевском у преради М. М. Пешића”, режирао је Тито Строци. Премијера је била 30. децембра 1937. Улоге су тумачили: Мата Милошевић (Кнез Мишкин), Миливоје Живановић (Рогожин Парфен Семјонич), Блаженика Каталинић (Барашкова Настасја Филиповна) и други.

По речима др Николе Мирковића, основни утисак прераде је да су у питању

[...] инсиенисани одломии из романа, често сажети и комбиновани, а не драмска радна која се развија сама из себе, без икаквих помоћних епских елемената. [...] Режија је интелигентан покушај, али није премостила празнине између слика. Претеривағе у глумачкој игри најмане код М. Милошевића, юегов Мишкин је анђеоска доброта. (Мирковић 1938)

О представи детаљан приказ пише Велибор Глигорић. Прво, Глигорић се бави драматизацијом М. М. Пешића, који се нашао пред деликатним задатком да обиман роман Идиот сажме у једно позоришно вече. Али, као и увек критичар је двосмислен:

Мора се признати г. Пешићу да је ипак, и поред велике жртве текста романа захтевима позорнице, прилично изашао на крај са овим задатком. Он је сабрао најживта драматична места у ро- 
ману која рељефбо приказују повест романа. [...] садржина романа растерећена од многих странииа које илуструју идеје Достојевског немају великог интереса за данашњииу. [...] С друге стране драматизација је у сажиману направита крупне прескоке због којих су поступии и сукоби личности. [...] остали прилично необјачғени и загонетни за публику, којој је текст романа или сасвим непознат, или јој није више жив у сећағу. [...] Драматизација није обрадила толико психолошку и моралну личност кнеза Мишкина, колико однос између Мишкина, Настасје и Аглаје. [...] Празнина се осетила нарочито после драмски маестралне, узбудливе и психолочки компликоване сиене на вечери код Настасје, сцене коју је драматизација у тексту очувала и успешно пренела на позорнииу. После те сиене драматизација оставља утисак као да је роман преломила на пола. [...] Режија г. Строиија (питать редитель спада међу болне тачке београдског позоришта), на приказу овог дела био је прилично тежеран и театарски површан. [...] карактеристике уметничке и психолошке снаге Достојевског нису биле тако блиске неговим редитетьским способностима као и то да је за приказ потребан стил и начин рада Художественог театра. [...] У приказу нису биле корисно подельене улоге према глумачким способностима и наклоностима. Било је сасвим неупутно додељиване улоге Аглаје г-ици Урбановој којој тај тип тичности нимало не одговара. Г-иза Урбанова, иначе даровита глумица, развијала је у Аглаји прекомерно хистеричност и поврину тьутитост у мазнон каприиу, запостављајући потпуно јаку и пркосну интелигенцију, развијени дух, затворени карактер, сумор, охолост, психолошки контраст у скривеном дивлену према простодушности кнеза Мишкина (било би умесније да је ову улогу играла г-ђа Ризнић). Улоге видно промашене биле су и г. Л. Јовановића који је лоше схватио Лебедева, карикирајући плитко ғеггову понизност и г. Н. Јовановића који је Фредишченка карикирао у врло вулгарном и баналном такрдијаштву. [...] Није далеко од ове промашености била ни игра Г. Дрнића који је Гату приказао у салонској повриности. [...] Нема ни моћнијег израза унураште борбе која узбудливо суочава Настасју и Аглају... Том одсуству трагичног изражаваюа допринела је и једнострана и плитка игра г-ђе Каталинић у тумачену Настасје. А Настасја је веома компликована тичност и спада у ред најснажнијих и најинтересантнијих жена које смо сусрели код Достојевског. [...] Више успеха имао је г. М. Милошевић у игри кнеза Мишкина. Г. М. Миточевић је успео да изрази зрачно човекољубље, питому срдачност 
кнеза Мишкина, безазленост юеговог карактера. [...] Г. Живановић је много болье изразио жестину и грубо пустахиство Рогожина него узаврелост страсти које овога прождиру, него ти и оно што је у Рогожину меко, осећајно и болећиво, ону скрушеност и страх у близини Настасје. [...] Г-ђа Таборска, стара трагеткиға минуле епохе начег позоришта имала је да тумачи занимтиву личност генералище Лизавете Прокофјевне. Г-ђа Таборска показала је лепо уживлаване у детинасту осетливост, добродушност и природну отвореност генералице. [...] Г. Никачевићу је пало у дужност да илуструје пијанииу и маштала генерала Ивољгина. Г. Никачевић га је приказао ретьебно, импозантно у теговој патетичној пози и говорничкој свечаности. Захтевало би се ипак од г. Никачевића више израза занесености у екстази, трагичнијих потеза у илустроваюу унутрашнег слома генерала Ивољгина. (Глигорић 1938)

Душан Крунић запажа да је улогу Аглаје погрешно тумачила Невенка Урбанова „Аглаја је горда, и паметна, а никако усплахирена и раздражена зверчица, како ју је приказала г-ђа Урбанова. Један део кривице пада и на г. Строција." (Крунић 1938)

Адаптацију Идиота, у једанаест слика, Давида Лазаревича Таљникова (Давид Лазаревич Тальников), превео је Павао Циндрић, а режирао и сценографски уобличио Бојан Ступица, костиме је урадила Вера Борошић, избор музике Драгутин Савин, корепетитор је био Зденко Марасовић, а помоћник редитеља Фрањо Термачић. Премијера је одржана 6. новембра 1959. Главне улоге тумачили су: Васа Пантелић (Кнез Мишкин), Љуба Тадић (Парфјон Рогожин), Мира Ступица (Настасја Филиповна) и други.

Редитељ представе, Бојан Ступица сматрао је Идиота, тј. кнеза Мишкина „човеком чистог срца, али без снаге у свом непрестаном сукобу са оним нужностима које живот собом доноси. То је некакав руски Хамлет, који се у додиру са стварношћу распрскава као стаклена посуда" (Ступица 1959). Критика је била подељена у оцени драматизације Таљникова, који окупља јунаке око Настасје Филиповне (Мира Ступица) и тако добија чист драматуршки ток и јединствену акцију, односно неминовно добија облик сценских илустрација романсијерског текста, испуњених дугим монолозима, те доноси само површински слој смисла Достојевског. Ступица је своју имагинацију подредио писцу и раду с глумцима, његова сценска визуелна решења изванредно су функционална, а успе- 
ху је свакако допринела игра Мире Ступице. Представа ипак предуга, губи темпо како одмиче. Ели Финци издваја улогу Рогожина

О идејним и гудским основама на којима је љуба Тадић изградио лик Рогожина, дало би се са озбиљним разлозима спорити, али он је био у једној особеној интерпретаиији, тако страсно и узбудљиво глумачки остварен једноставним изражајним средствима, да је свакако био најближи аутентичном Достојевском, оном из романа, и тако реализовао најузбудљивије уметничке тренутке вечери. Чини ми се да је први пут Тадићева глумачка сировост, тако снажна и природна, добила патину рафинираности и лепоту мајсторског нијансирана. (Финци 1959)

Љуба Тадић је за улогу Рогожина, 1960. добио Октобарску награду.

Идиота, по драматизацији Анджеја Вајде, названој по главној јунакињи, Настасја Филиповна, за сцену Народног позоришта адаптирала је и режирала Мира Ерцег. Драму с пољског језика је превео Петар Вујичић. Сценографија је припала Снежани Петровић, костим Љиљани Драговић, композитор је био Иван Стефановић, кореограф Владимир Логунов. Премијера је одржана 10. маја 1986. Насловна улога припала је Јелени Шантић, кнез Мишкин био је Предраг Ејдус, а Рогожин - Данило Лазовић.

Представа стиче статус култне за мање од месец дана приказивања, најпре због врло маштовите замисли редитељке да уведе лик Настасје Филиповне у комад за два глумца - сценски је материјализовала као злодуха који их прогони у сну - и да радњу сагледа од краја, у ретроспекцији. Изврсна глума и плес следе редитељку у обликовању необично суптилне и жестоке представе префињених слика и високо култивиране атмосфере. Колико вреде култне представе говоре сведочења оних којима се урезала у меморију, оног тренутка кад је престала да се изводи, јер је Настасја Филиповна имала сценски живот пуних седам година. У антологијској представи играли су маестрални Данило Лазовић (Награда НП-а 1986.) у улози Рогожина, Предраг Ејдус у улози кнеза Мишкина за коју је добио и награду „Златни ловоров вијенац” (30. МЕСС, Сарајево, 1989) и изузетна Јелена Шантић у улози Настасје Филиповне. ${ }^{3}$

3 Године 1992. драматизација Анджеја Вајде, под насловом Настасја Филиповна, играна је на сцени Покрајинског народног позоришта у Приштини (Албанска драма) у режији Сељами Таракуа. Драматизацију с пољског на албански језик урадио је Екрем Баша. 
На сцени Народног позоришта Идиот, у драматизацији и режији Стеве Жигона, премијерно је изведен 22. новембра 1995. Сценографију је радио Борис Максимовић, а костим Божана Јовановић, избор музике Петар Антоновић. Главне улоге су играли: Небојша Дугалић (Мишкин), Ивана Жигон (Настасја Филиповна), Тихомир Арсић (Рогожин).

Критика је била сложна у оцени: Жигон је успео да дочара проблематику романа, атмосферу руске средине у сажетој и напетој сценској формули. Први део је с маестралним слухом за сценске карактере и драмске епицентре, док други део представу спушта на ниво општих позоришних и филозофских места (Волк 1995).

„Стево Жигон је у неколико сцена у Идиоту показао мајсторство свог читања, - пише Драгана Бошковић, - Величанственом завршном сценом, у којој Мишкин (Небојша Дугалић) и Рогожин (Тихомир Арсић) живе логос над мртвом Настасјом Филиповном (Ивана Жигон), Жигон је показао како драма апсурда има јаке и дубоке корене у људској психи и историји света" (Бошковић 1995). Бранка Криловић је пласирала један од најбољих приказа

Прођите поред нас и опростите нам нашу срећу - та реченица из представе Идиот коју изговара Небојша Дугалић с најнемирнијим миром и болесно чистом савешћу, јесте, можда најснажнији сигнал yпућен човечности [...]. Са бременом те огромне уметничке и људске одговорности Небојша Дугалић креће да живи кнеза Мишкина, да юегову чистоту учини могућном, да нима потре зло, неморал и лажна осећана. Дугалић то чини снагом своје крхкости. [...] Насупрот тој господској и опојној Дугалићевој тананости, хуји и грми Рогожин Тихомира Арсића, Рогожин с главом узаврелом од страсти која нема времена и морала, али којој не манка емоција...Таквог Рогожина пожелео би сваки Достојевски. Као инспирација мушких фантазија и женских мора, Ивана Жигон ће од самог почетка...сву енергију драме држати под претюом непогоде и олује из Настасјиних халина. [...] Нагађајући жанр Настасјине туге, Ивана Жигон варира од Кочтаниног контраверзног одрииана до мангуплука Елизе Дулитл. Њена сиеничност и женствена супериорност...дају јој за право да искуша још ко зна која умећа. Јер она ће још дуго бити пожелна Настасја Филиповна...Ако смо посумғали да нам још само Достојевски фали, постидеће нас Сергеј Трифуновић, танки, бледи момак у кошуљи Иполита. Глумчина из чијег лика ће 
зацвилети много осујећене младости. Господин Марко Николић у улози Лебедева и Славка Јеринић као Јепанчина, изванредно су се носили са јаком, младом конкурениијом. Готово модерна девојачки је бескрупулозна Аглаја Данијеле Кузмановић Павловић. И не само они. [...] комплетан ансамбл под прецизним вођством Стева Жигона, импресивна сиенографија Бориса Максимовића, музика Петра Антоновића, костими Божане Јовановић, допринели су монументалности представе. Шта је било, било је, али Стево Жигон је још увек мајстор режије. (Кириловић 1996)

На додели награде „Раша Плаовић”, Тихомиру Арсићу, Мухарем Первић рекао је:

Додельуући улогу Рогожина Тихомиру Арсићу редитељ је изложио ризику себе, представу и Тихомира Арсића. [...] И једном и другом, и Жигону и Арсићу, Бог и Достојевски... били су у помоћи... Тихомир Арсић је направио улогу која га уврићује у прворазредне глумие, а Стево Жигон и Народно позориште представу која би без креације Тихомира Арсића остала без битног ослония и динамичког средишта. (Первић 1996)

Представа је на репертоару, закључно са сезоном 2005/06, одиграна 80 пута.

\section{Младић}

Младић у преводу Милоша Ивковића, драматизацији и режији Стеве Жигона, изведен је на сцени Југословенског драмског позоришта 13. априла 1975. Сценограф је био Петар Пашић, костимограф Божана Јовановић, а музику је компоновао Баронијан Варткес. Главне улоге играли су: Александар Берчек (Аркадије Макарович Долгоруков), Олга Савић (Софија Андрејевна), Стојан Дечермић (Андреј Петрович Версилов), Радмила Ђурђевић (Лизавета Макаровна), Мирјана Вукојчић (Ана Андрејевна) и други.

У режији Стеве Жигона све је било доведено до перфекције и био је очигледан труд уложен у поставку. О представи као „конструктивистичкој хроници” писао је Петар Волк „Највише простора за игру имао је Александар Берчек у улози младог Долгоруког. [...] то је био за Берчека успех који се не може оспорити. Његову мајку, Софију донела је 
као благу и осећајну жену Олга Савић. Спахију Версилова тумачио је романтично Стојан Дечермић." (Волк 1975). Представа је указала могућност ка другачијим и слободнијим театарским формама. У одлуци Жирија за доделу награде Бојан Ступица, Савеза драмских уметника Србије (у саставу Божидар Дрнић, Татјана Лукијанова и Дејан Мијач), могло се прочитати следеће:

Стево Жигон, једна од најистакнутијих театарских личности у Југославији, редитель. [...] понудио је своју визију Младића [...] Своје читаюе Достојевског, Жигон нам приказује као мичьете преточено у слике. Служећи се визуализацијом драмских елемената као редительским принципом, он је понудио гледаоцима представе широку гаму за чулну периепиију, досегао у неколиким призорима тренутке изванредне ликове лепоте и најзад остварио одговарајућа зрачетьа. Овај поступак, чијим се резултатом јавль једна лепа и мудра представа, учинио је да жири да превагу Жигоновој режији над осталима у конкуренцији. (Волк 1975)

\section{Браћа Карамазови}

Драматизација романа Браћа Карамазови, под насловом Сладострасниии-Карамазови, премијерно је изведена у Атељеу 212, 15. јануара 1974. Према преводу Јована Максимовића, текст је адаптирао и режирао Предраг Бајчетић. У позоришним круговима коментарише се да је Бајчетић уложио огроман труд у Сладостраснике, написавши нову драму користећи скоро цео опус Достојевског. Дејан Пенчић Пољански говори:

Бајчетић се држао литерарног казиваюа, монтирајући реплике из разних дела, одузимајући их и додетьјући, по сопственом нахођену личностима преузетим из романа или тичностима које је сам конструисао. [...] У овом 'комадану Потске', најгоре је прошао Иван Карамазов. Његов текст говоре сви. [...] Можда зато да се покаже како је Иван у свима. [...] Није тако глумичма. Уместо студираға улога, тихов рад је ишао у правиу свега што су од Достојевског раније прочитали [...]. Ако је за трен велики писаи био присутан онда су за то заслужни Данило Стојковић, као Фјодор Карамазов, Петар Крат, нарочито у монологу о Великом инквизитору, и Петар Божовић (Аточа), који је умео да ћути, док је текст повремено 
звучао празно и тажно, нарочито пасажи преузети од Ивана Карамазова. Љиљана Драгутиновић, ново тище позоришта, наметнула се у представи, више талентом него резултатом. [...] Сценографија Слободана Машића и костими Божане Јовановић, једноставни и ликовно ебектни. (Пољански 1974)

Критичар Јован Христић примећује да је адаптацијом Предраг Бајчетић хтео да на једно место окупи неке основне теме Достојевског али:

[...] адаптација је најслабије место представе. [...] Врлина представе су Данило Стојковић (Фјодор Карамазов) и Петар Крать (Просјак, бивщи офищир). Данило Стојковић је један од ретких наших глумаца, који глуми читавим телом и зато нам је юегов Фјодор пружио право уживағе [...]. На истом путу је био и Петар Крат...спојио је речи и тело и ми смо видели како се оне рађају из тела разореног алкохолом и сиромаштвом. [...] Врхунаи улоге је на самом крају представе, юегово велико обраћаюе Христу. Слушали смо без даха тај говор и када је завршио, видели смо нешто чему се може дивити само у тишини. Те две улоге биле су довољне да се искупе више од једне представе, а било је потребно само још мало да се придружи и трећа - Петар Божовић као Аљоча Карамазов. [...] Јер, колико уме да придобије, Бајчетић уме и да одбије гледаоиа. Он је редитељь чија свака представа има јасну и често значајну идеју [али има мало смисла за тактику са гледаоцима, прим. аут.]. (Христић 1977: 66-68)

Браћа Карамазови су у драматизацији Андреје Хинга и режији Љубише Георгијевског изведени на сцени Народног позоришта 20. марта 1984. Сценографију је реализовао Владимир Маренић, костиме Божана Јовановић, а музику Зоран Симјановић. Играли су: Бранислав Јеринић (Фјодор Карамазов), Петар Банићевић (Дмитриј Карамазов), Милош Жутић (Иван Карамазов), Предраг Ејдус (Алексеј Карамазов), Павле Минчић (Смердјаков) и други. Поставка је окарактерисана као неспоразум с Достојевским или пак редитељски промашај, те није била догађај за памћење.

Глумац Небојша Дугалић је изабрао лик Дмитрија Карамазова за монодраму под називом Исповест Дмитрија Карамазова, чија је премијера била 30. јануара 2013, на Малој сцени Позоришта Мадленијанум. Био је то Дугалићев пројекат за који 2011. у Москви на фестивалу „Златни 
витез” добија награду Сребрни витез, а потом 2012. отвара Фестивал монодраме и пантомиме у Земуну.

У Позоришту „Славија”, 14. септембра 2013, приказана је представа Карамазови / Сабласни Ерос, у режији Владимира Лазића, драматизацији Милисава Миленковића, сценографији Бориса Максимовића и костимима Данице Ракочевић. У представи играју: Михаило Јанкетић (Фјодор Карамазов), Милан Прљета (Дмитриј Карамазов), Жарко Степанов (Иван Карамазов), Небојша Ђорђевић (Аљоша Карамазов), Сања Радишић (Грушењка), и Ивана Ковачевић (Катарина). Редитељ Лазић био је најзаслужнији за успех представе, јер све елементе поставке је смело осмислио и уклопио. Максимално је искористио простор сцене позоришта а од целе глумачке екипе извукао оно најбоље. Представа је била прави подвиг Позоришта Славија.

\section{Уместо закључка}

36

Истражујући један мали сегмент рецепције дела Ф.М. Достојевског, на српској сцени, на примеру једног града, у временском низу и трајању током два века, можемо закључити, да је великан светске књижевности, савременик доба, у којем живимо. Дела Достојевског живеће и у будућности, јер се баве вечним темама малих људи, њиховим заблудама, притајеним злом, лошим намерама, али и патњом, љубављу и на крају покајањем. Многе инсценације заслужују да буду уписане у историју српског позоришта. У овом прегледу сценских поставки очигледно је да адаптирано дело Достојевског, трпи и превазилази сва искушења. Од великана редитељске инсценације као што су Ракитин, Ступица, Жигон, Савин до младих нараштаја данашњице. Такође, слободно можемо тврдити, да су током два миленијума стасавале многе глумачке генерације, као и бардови позоришне сцене. Преглед треба да користи генерацијама позоришних стваралаца који долазе, јер налазе већину одговора на питања ко, где, како, на који начин, колико успешно је извођено дело Ф.М. Достојевског на домаћим позоришним сценама.

\section{Литература и извори}

- Арсић А. Приказивачи вештина, МПУС, 2001.

- Бошковић Д. „Идиот”, Експрес, 27-29. новембар 1995.

- Волк, П. „Глумци”, Кюижевне новине, Београд, 23. новембар 1968. 
- Волк, П. „Злочин и казна”, Книжевне новине, 27. март 1971.

- Волк, П. „Село Степанчиково”, Книжевне новине, 1. април 1974.

- Волк П. „Младић”, Кюижевне новине, 16. мај 1975.

- Волк П. „Зли дуси”, Илустрована политика, 20. март 1984.

- Волк, П. Преображене: Драма Народног позоришта у Београду од 1868. до 2007. године, „Алтера”, Београд, 2009.

- Глигорић, В. „Достојевски у данашњици” („Злочин и казна” у драматизацији Краснопољског) Политика, 28. март 1935.

- Глигорић В. „Идиот” од Достојевског (У драматизацији М.М.Пешића и режији Т. Строција) Политика, 1938) 3. јануар 1938.

- Документација МПУС и НПБ; годишњаци Стеријиног позорја.

- Јовановић, С. „Злочина и казна”, у: Позорищне студије и критике, Београд, 1993.

- Криловић Б. Дневник, ТВ Београд, 29. фебруар 1996.

- Крунић Д. „Прича о овчици Божјој”, Правда, 02. јануар 1938.

- Комненић, Б. „Ово је време за зле духе”, Политика, 09. новембар 2011.

- Мирковић, М. „Достојевски је Русија”, Експрес политика, 5. новембар 1968.

- Мирковића, Н. „Идиот”, Десет слика по Достојевском у преради М.М. Пешића, Време, 1. јануар 1938.

- Мујчиновић, А. Стево Жигон: „Зли дуси”, Експрес, 8. март 1984.

- Первић, М. „Зли дуси”, Политика, Београд, 6. новембар 1968.

- Первић, М. Додела награде „Раша Плаовић”, Политика, 23. новембар 1996.

- Петровић, Ж. Репертоар Народног позоришта у Београду, 18681914, МПУС, Београд, 1993.

- Пољански, Д. П. Виђеюь, 18. март 1974.

- $\quad$ Пољански Д. П. Културна панорама, Радио Београд, 16. јануар 1974.

- Пољански, Д. П. Културни девник, Радио Београд, 16. децембар 1976.

- $\quad$ Пољанског, Д. П. Седам уметности, Радио Београд, 28. јун 1982.

- Селенић С. „Злочин и казна”, Народни студент, Београд, 23. децембар 1953.

- Селенић, С. „Туђа жена и муж под креветом”, Ексnрес, 17. децембар 1976.

- Стаменковић, В. „Злочин и казна”, НИН, 7. фебруар 1992.

- $\quad$ Стаменковић, В. Верни духу оригинала, НИН, 10. XI 1968.

- Стојковић Р., Српске позоришне награде, издање аутора, Београд, 2008. 
- Ступица Б. „Идиот” „Политика”, 31. новембар 1959.

- Тадић, Љ. у: Љуба Тадић,човек сцене и живота. Јагодина „Дани комедије", 2002.

- Финци, Е. „Злочин и казна”, Политика, Београд, 26. новембар 1953.

- $\quad$ Финии Е. „Идиот”, Политика, Београд, 8. новембар 1959.

- Финци Е. „Кротка и Госпођица Јулија”, Политика, 5. март 1961.

- Финци Е. Више и мағе од живота I, II, II IV, V. Београд: Просвета, 1953-1971.

- Христић, J. Позориште, позоришта, Београд, 1977.

- Христић, Ј. Позоришни реберати, Београд 1992.

- Цветковић, С. В. Репертоар Народног позоришта у Београду 18681965, МПУС, Београд. 
Dragana Čolić Biljanovski

Faculty of Dramatic Arts, Belgrade

\title{
WORKS OF FYODOR MIKHAILOVICH DOSTOEVSKY ON BELGRADE THEATER STAGES
}

\begin{abstract}
The aim of the study is to present stagings based on the works of F. M. Dostoevsky on Belgrade's theatrical stages (National Theatre, Yugoslav Drama Theatre, Belgrade Drama Theatre, Atelier 212, Madlenianum Theatre, Slavija Theatre) during the twentieth and the first two decades of the twenty-first century. We conducted the research applying the archival-historical method on the material of reviews and reviews of theatre plays, which were published in the daily press (Politika, Pravda, Vreme, Ekspres), periodicals (Književne novine, Nin) and separate studies and manifolds, prominent theatre critics and theorists, namely Dušan Krunić, Velibor Gligorić, Eli Finci, Petar Volk, Jovan Hristić, Slobodan Selenic and others. In addition, TV and Radio records, bibliographic publications and other archival materials were used in the paper.
\end{abstract}

Keywords

Fyodor Mikhailovich Dostoevsky, Belgrade, theater, dramatization, play

Primljeno: 8.8.2021.

Prihvaćeno: 26.8.2021. 